\title{
Neuroanatomical Structures Underlying the Extinction of Drug-Seeking Behavior
}

\author{
Richard M. Cleva* and Justin T. Gass
}

Center for Drug and Alcohol Programs, Department of Psychiatry and Behavioral Sciences, Medical University of South Carolina, 67 President Street, MSC 861, Charleston, South Carolina 29425, USA

\begin{abstract}
This review summarizes current knowledge about the neurobiological components underlying the extinction of drug-associated memories and how they may contribute to the treatment of drug addiction. Evidence suggests that extinction learning is not the forgetting, or unlearning, of the associations between external stimuli and drug effects, but that new reinforcer expectancies are necessary for extinction of drug-seeking behavior to take place. Several theories suggest that addiction is a disorder of learning and memory, and recent evidence indicates that the brain circuits, neurotransmitters, and signal transduction mechanisms that underlie drug addiction are similar to those that mediate learning and memory processes. According to these theories, drug addiction results from repeated drug use and the formation of lasting associations between a drug's effects, withdrawal symptoms, and the environmental cues and contexts within which they are experienced. Unfortunately, standard behavioral modification techniques, such as cue exposure therapy, have shown only moderate efficacy in reducing and/or extinguishing the salience of drug-associated cues and contexts. Therefore, a greater understanding of the neurobiological mechanisms involved in the extinction of drug-related memories could provide novel therapeutic interventions for the treatment of drug addiction.
\end{abstract}

Keywords: Addiction, extinction, learning, neurobiology, drug memories, treatment, drug context.

\section{INTRODUCTION}

Drug addiction is a disorder of the nervous system marked by a transition from intermittent drug use to compulsive, uncontrolled drug intake and repeated attempts at abstinence and relapse. It is now apparent that the brain circuits, neurotransmitters, and signal transduction mechanisms that underlie drug addiction have considerable overlap with those mediating normal learning and memory processes [1-4]. Therefore, drug addiction has been theorized to be a disorder of learning and memory [1-11]. Many of these theories suggest that drug addiction results from instrumental and associative overlearning whereby drugs and environmental cues and contexts become hypersalient leading to drug craving and relapse [12-14]. As a result, long-term drug use leads to the formation of compulsive, habitual, and ritualistic drug-taking behaviors

Attempts to extinguish the salience of drug conditioning by behavioral modification techniques such as cue exposure therapy have only shown limited success [12, 15-19]. Additionally, most current behavioral and pharmacological treatments for addiction center on eliminating withdrawal symptoms or reducing drug intake with little focus on the process of extinction. A greater understanding of the neurobiological mechanisms involved in the extinction of drug-related memories and drug-seeking behaviors could provide novel therapeutic interventions for the treatment of drug addiction.

*Address correspondence to this author at the Center for Drug and Alcohol Programs, Department of Psychiatry and Behavioral Sciences, Medical University of South Carolina, 67 President Street, MSC 861, Charleston, South Carolina 29425, USA; Tel: 1-843-792-1134;

E-mail: cleva@musc.edu
The majority of studies examining the neural mechanisms of extinction have focused on either appetitive conditioning (e.g., extinction of consummatory behavior related to natural rewards such as food or sucrose) or aversive conditioning (e.g., extinction of fear-related behaviors following pairing of environmental stimuli with electric footshock). However, relatively few studies have attempted to identify the neural mechanisms that underlie the extinction of addiction-related behaviors such as compulsive drug-seeking and conditioned associations between drugs of abuse and environmental stimuli.

\section{WHAT IS EXTINCTION?}

Extinction is defined as the gradual elimination of a learned response that occurs when the response is no longer reinforced or the unconditional stimulus (US) is no longer presented in conjunction with the conditioned stimulus (CS). Thus, after the repeated pairing of a discrete CS (e.g., light) with US (e.g., shock) the CS will elicit specific behaviors because the CS now predicts the availability of the US. With repeated presentations of the light without the shock, the conditioned response dissipates, or is extinguished, since the light no longer "predicts" that the shock is imminent. Within the context of drug addiction, a drug (US) is often administered in a particular context (CS). In the same manner that a light can be conditioned to elicit behaviors related to the presence of a shock, cues conditioned to drug availability can elicit behaviors that induce drug use (e.g., craving). The process of extinction differs from that of reconsolidation, which is the process of restabilizing a memory after it has been reactivated through stimulus reexposure [20,21]. While yet to be shown experimentally, it is believed that reconsolidation would enhance a specific association between a drug and environmental stimulus. 
Alternatively, disruption of this process causes amnesia [22, 23]. This knowledge has led to a resurgence of interest in the extinction process as a potential treatment strategy for drug addiction. Extinction, in theory, would serve to create new associations that would replace the initial learning of the association between a drug's subjective effects, environmental cues, and persistent maladaptive memories [24].

\section{EVIDENCE THAT EXTINCTION IS NEW LEARNING}

For many years following landmark studies by Ivan Pavlov and B.F. Skinner in the fields of associative and operant learning and memory, it was assumed that the extinction of classically- and operantly-conditioned behaviors was a process of "forgetting" or "unlearning" of the relationships between external stimuli and behavioral responses. However, over the last two decades there has been a tremendous amount of evidence that the extinction process is a form of new and active learning that challenges the previously held belief that extinction is simply forgetting or weakening of learned associations. This is evidenced by the fact that:

1. Drug-seeking behavior can be reinstated by several stimuli including a priming injection of the drug, presentation of drug-associated environmental stimuli, or exposure to an acute stressor without the need for additional behavioral training in a phenomenon known as reinstatement [25-40]. The fact that no added behavioral training is necessary suggests that a memory trace of the original association remains intact. Therefore, extinction is likely to incorporate the formation of new stimulusreward associations.

2. Drug-seeking behavior can spontaneously resume following extensive extinction training [15, 41-44] in a process known as spontaneous recovery. This behavior suggests that the neural processes underlying drug self-administration remain intact.

3. Extinction of conditioned behaviors is context specific [45-51]. Take, for example, the renewal effect or contextual reinstatement. This is the phenomenon by which animals are trained to selfadminister a drug in one environment and then that behavior is extinguished in a different environment. If the animal is placed back into the environment where the contingencies were originally established, drugseeking behavior will resume [52].

4. The re-training of animals to self-administer a drug following extinction takes significantly less time compared to the initial training process $[53,54]$. This process is known as reacquisition and suggests that the original learning during training of the selfadministration procedure generally remains unaltered.

5. Studies utilizing fear conditioning show that extinction training induces cellular neuroadaptations that underlie normal learning and memory, such as long-term potentiation (LTP) and de novo protein synthesis [55, 56]. This evidence reveals that the neural mechanisms mediating learning and memory may also contribute to extinction training and that extinction is indeed a process of new and active learning.
These lines of evidence suggest that extinction learning is not the "forgetting" of previously learned contingencies between environmental stimuli and drug availability. Instead, it appears that the original associative and instrumental learning that takes place during the initial stages of addiction remain intact, and for extinction of drug-seeking behavior to take place, there must be a formation of new reinforcer expectancies [47].

\section{RODENT MODELS OF DRUG ADDICTION AND EXTINCTION LEARNING}

Several animal models, primarily using rodents, have been developed to study the various aspects of drug addiction $[25,26]$. Those procedures that are most appropriate for the study of extinction learning include the intravenous drug self administration (IVSA), conditioned place preference (CPP), and cue- and context-induced reinstatement of drug-seeking behavior paradigms.

\section{Conditioned Place Preference (CPP)}

In the CPP paradigm, the animal learns to associate the subjective and physiological effects of a passively administered drug with the environmental context in which it is received. A typical CPP apparatus consists of two separate compartments. Each compartment has unique tactile and visual characteristics and together, they are connected by a neutral "start" box. Both compartments are typically equipped with photobeams that detect the presence and measure the locomotor activity of the animal. During the initial phase of the experiment, the animal is allowed access to both compartments for a set amount of time in order to determine preference (measured by total time spent in each compartment) between the two environments. Next, the animal is injected with a neutral substance (e.g., saline) and is confined to the initial preferred environment. On the following day, the animal is injected with the conditioning drug and confined to the initial non-preferred environment. This process is repeated for a set number of days (typically 4-6 times) and each animal receives equal pairings of the saline/context and drug/context. During the conditioning trials, the animal learns to associate the subjective effects of the drug with the unique physical characteristics of that compartment. In the final phase of the experiment, the animal is again allowed free access (in a drug-free state) to both compartments to determine the post-conditioning preference for each environment. If the animal now shows a significant increase in time spent in the drug-paired environment (the one that was initially non-preferred) then a CPP has been established and provides indirect evidence of the reinforcing effects of the drug. Multiple variations of the CPP procedure have been implemented (e.g., nonbiased design that results in no initial preference to either environment) and conditioned preferences have been established for nearly all drugs of abuse [57].

Similar to the IVSA paradigm, the CPP paradigm can be used to assess extinction learning. To accomplish this, the drug-paired side can be either repeatedly paired with saline or the established CPP can be allowed to dissipate over a period of time by repeatedly testing the animal's preference without further conditioning trials. Extinction of a CPP is typically measured in number of days required to reach extinction criteria and, as in the IVSA paradigm, a treatment 
that reduces the number of sessions required to reach this criteria is thought to reflect either enhanced extinction learning or disruption of drug/context memory availability.

\section{Intravenous Drug Self-Administration (IVSA)}

In the rodent IVSA paradigm, animals are trained to perform some type of operant task (usually a bar press or nose poke) in order to receive an intravenous infusion of, or access to, a drug. During the acquisition phase, animals are trained to perform the operant task with a non-drug reinforcer, such as food. Each reinforcer delivery is accompanied by the presentation of a visual and/or auditory stimulus (e.g. light or tone) that allows for the acquisition of a reinforcer/cue stimulus association. After the task has been successfully acquired, the non-drug reinforcer is replaced with an abused drug (such as cocaine, heroin, methamphetamine, nicotine, alcohol, etc.). During the maintenance phase, self-administration sessions are continued for a pre-defined number of sessions until responding for the drug becomes stable.

In the extinction phase, each previously drug-reinforced response results in either no programmed consequence or saline infusion. As extinction training continues, there is a gradual decrease in the number of responses that previously resulted in drug delivery; which is interpreted as the animal learning that the operant response no longer produces drug availability. An experimental treatment that decreases the number of tests required for predetermined extinction criteria is interpreted as either an enhancement of extinction learning or a disruption of drug/contextual stimulus memory availability. The previously reinforced operant response displayed during extinction training is referred to as drugseeking behavior because the response is not drugreinforced.

\section{Cue- and Context-Induced Reinstatement of Drug- Seeking Behavior}

The reinstatement model is a widely used animal model of relapse $[25-27,29,32,58,59]$ in which animals are trained to perform an operant task in order to receive an infusion of a drug. Cue-induced reinstatement examines the strength of the reinforcer/cue stimulus association acquired during self-administration. Following the initial training and extinction training described in the IVSA paradigm above, the animal is returned to the experimental apparatus and, in a response-contingent or non-contingent manner, presented with the cue previously associated with each drug infusion. Here, the animal's extinguished operant response is reinstated, although it does not actually result in the delivery of an infusion of the drug. This provides a tool for measuring the motivational salience of the cue, independent of the psychomotor effects of the drug. In a slightly different paradigm, context-induced or contextual reinstatement examines the associative strength of the physical environment in mediating drug-seeking behavior [52, 58, 6064]. Here, animals undergo extinction training in an experimental apparatus that is contextually unique from the apparatus where self-administration was acquired. This contextual change can involve modification of the floor, odor, and colors on the wall. Upon completion of extinction, the animal is returned to the original apparatus in which drug self-administration occurred. This reinstatement of context evokes an increased number of operant responses that previously resulted in the delivery of a drug as a result of the associative strength between the physical environment and drug.

\section{The Neurobiological Substrates of Extinction Learning}

There is a significant overlap between the neuroanatomical circuits and neurochemical substrates that underlie learning and memory processes and those that mediate drug addiction. For instance, both learning and memory and drugs of abuse induce LTP and long-term depression (LTD) [4, 6, 65-68]. Unfortunately, most of what is known about the neural mechanisms of extinction learning was derived from studies that use aversive conditioning (e.g., footshock) or appetitive conditioning with natural rewards (e.g., food). The extinction of conditioned fear in both animals and humans [69-80] as well as a cocaine CPP [8183] can be facilitated by the cognitive enhancing drug D-4amino-3-isoxazolidone [D-cycloserine (DCS)], which is a partial agonist at the strychnine-insensitive glycine site of $\mathrm{N}$ methyl-D-aspartate (NMDA) receptors [84, 85]. Nic Dhonnchadha and colleagues recently found that DCS enhances the extinction learning process and inhibits reacquisition of drug self-administration in rats trained to self-administer cocaine [86]. However, while the neural mechanisms involved in the extinction of a drug memory may be similar, it would be naïve to assume that they are identical to those involved in conditioning to non-drug reinforcers. Therefore, this review summarizes what is currently known about the neurobiological components underlying the extinction of drug-associated memories and how they may contribute to the treatment of drug addiction.

\section{THE PREFRONTAL CORTEX}

\section{Functional Role and Anatomical Connectivity}

The prefrontal cortex (PFC) is a collection of regions in the dorsal forebrain made up of the medial prefrontal cortex (mPFC), orbitofrontal cortex (OFC), and anterior cingulate cortex [87]. The mPFC is comprised of multiple subregions including the dorsomedial PFC (dmPFC), [comprised mainly of the prelimbic cortex (PrLC)], and ventromedial PFC (vmPFC), [mainly made up of the infralimbic cortex (ILC)] while the OFC is divided into medial (mOFC) and lateral (1OFC) sections. The PFC is considered the executive center of the brain due to its involvement in a multiplicity of functions. These include goal-directed behaviors, impulsivity and response inhibition, reward expectancy, salience attribution, emotional learning, drive and motivation, decision making, selective attention [88-91], memory consolidation, which can be defined as the process of stabilizing, storing, and strengthening new memories [92], as well as memory recall, which can be defined as the reactivation and/or retrieval of a previously consolidated memory [93].

The PFC is connected to a number of other brain regions including the brainstem, thalamus (which acts as an intermediary between the PFC and dorsal and ventral striatum), limbic system (including the amygdala and hippocampus), as well as other cortical regions [94-97]. The PFC interacts with other regions of the brain through a broad and diverse network of neurotransmitter systems [96] 
including afferent dopaminergic projections from the ventral tegmental area (VTA) [98], glutamatergic projections from thalamus, hippocampus, and amygdala [91]; efferent transmission to VTA and nucleus accumbens (Acb) [96, 99], gamma-Aminobutyric acid (GABA) interneurons [100, 101]; serotonergic innervation from the median and dorsal raphe nuclei [102-104], noradranergic innervations from the locus coeruleus [105-107], and cholinergic innervation from nucleus basalis magnocellularis, diagonal band, and mesopontine laterodorsal nucleus [108-111]. Moreover, there are also various peptidergic systems present within the PFC including opioid peptides, cholecystokinin (CCK), neurotensin, neuropeptide Y (NPY), and corticotropin releasing factor (CRF) [112].

\section{Role in Extinction Learning}

There is extensive research implicating the PFC in the extinction of conditioned fear (see [113-115] for comprehensive reviews). Fear conditioning is a form of classical conditioning in which a particular neutral context (e.g., operant chamber) or neutral stimulus (e.g., light or tone) is paired with an aversive stimulus such as an electric footshock. After repeated pairings, presentation of the neutral stimulus elicits fear, which can be measured with galvanic skin response and/or freezing behavior (e.g., crouching time).

Evidence suggests that the PFC plays a critical role in the consolidation of extinction learning [116]. Lesions or temporary inactivation of the ILC and VmPFC inhibit extinction of conditioned fear [113, 115, 117-125], block retrieval of extinction learning [116], and result in behavioral perseveration in both rodents [120] and primates [88]. Inhibition of protein synthesis or mitogen-activated protein kinase (MAPK) activity [126-128], antagonism of NMDA receptors [129-130], as well as pharmacological inactivation of the ILC impairs extinction memory and the retrieval of a consolidated memory [122]. The vmPFC role in the consolidation of extinction learning might involve regulation of NMDA receptors that mediate molecular cascades necessary for normal learning and memory as recent animal research shows that inactivation of vmPFC NMDA receptors [via NMDA antagonist 3-(+-)2-carboxypiperazin-4yl propel1 phosphate (CPP)] inhibits extinction learning [129]. PFC stimulation enhances extinction of conditioned fear [131133] and neurons in the PFC have been shown to alter their transmission during extinction training [131]. Furthermore, human imaging studies show a positive correlation between activity levels in the vmPFC and extinction of conditioned behaviors [134, 135].

Much less is known about the PFC's role in extinguishing drug-related memories and drug-seeking behavior, but there appears to be considerable overlap between those mediating extinction of fear and drug conditioning (see [136] for a recent review). Peters and colleagues have shown that enhanced activity in the ILC inhibits drug-seeking and blocks reinstatement [137]. Pharmacological inactivation of the ILC facilitated the reinstatement of drug-seeking behavior whereas activation of the ILC with $\alpha$-amino-3-hydroxyl-5-methyl-4-isoxazolepropionate (AMPA) blocked the reinstatement of cocaineseeking behavior. Furthermore, unilateral inactivation of the nucleus accumbens shell (AcbSh) had little effect on reinstatement of drug-seeking behavior whereas simultaneous inactivation of the AcbSh and ILC attenuated cocaine-seeking behavior. These results suggest a unique pathway between the ILC and AcbSh that regulates extinction of drug-seeking behavior [137].

Available evidence suggests that long term drug exposure reduces functionality and activity in the PFC [138, 139] and that this reduction of activity and functionality inhibits impulse control and fosters the development and/or enhancement of incentive salience attributed to drug-related cues and memories [138, 140]. It's worth noting that drug addicts exposed to drug-associated stimuli show increased activation within the OFC and ACC [141-149], possibly due to the inhibition of brain regions that are necessary for extinction learning [142]. One study in non-human primates supports the notion that the PFC regulates the transition from automatic to controlled behaviors [150], which could be helpful in understanding why a drug addict would struggle in attempting to self-regulate behaviors that are compulsive and uncontrolled.

\section{The Amygdala}

\section{Functional Role and Anatomical Connectivity}

The amygdaloid complex is a part of the limbic system located within the temporal lobe ventral to the caudateputamen $(\mathrm{CPu})$ and globus pallidus (GP) and lateral to the piriform cortex (Pir). The amygdala is made up of four major subdivisions, including the basal subdivision [mainly comprised of the basolateral amygdala (BLA)], the medial subdivision (which includes the basomedial nucleus, intraamygdalar stria terminalis, intercalated nuclei of the amygdala, and medial amygdala), the lateral subdivision (or, lateral amygdala), and the central subdivision (central nucleus of the amygdala). The amygdala is involved with various learning and memory processes including the formation and consolidation of emotional memories [151, 152]. More specifically, the BLA plays a crucial role in the synaptic plasticity associated with emotion-related behaviors and processing of emotionally significant stimuli [10, 134, 152-157] as well as the formation of stimulus-reward associations [33, 158-164].

Within the amygdala there is a broad and diverse network of neurotransmitter systems [165] including glutamatergic, cholinergic, GABAergic, dopaminergic, noradranergic, and serotonergic terminals and receptors. Neuropeptides such as enkephalins, CRF, NPY, and CCK and their receptors are also present in the amygdala. Afferent and efferent sources and targets include all sensory cortices, PFC, medial temporal lobe/hippocampus, hypothalamus, bed nucleus of the stria terminalis, brainstem, and striatum (involved only in efferent activity) [166]. The amygdala receives sensory input from all of the sensory cortices and contextual/episodic information from the hippocampus and these connections may mediate the formation of drug-related memories [167]. Efferent projections, possibly underlying activation of the neurocircuitry mediating reward/reinforcement, are sent from the amygdala to the VTA and Acb. Additional efferent signals are sent from the amygdala to the hippocampus, $\mathrm{CPu}$, and frontal cortex possibly facilitating contextual learning 
and memory, motor learning, and activation of the executive control center of the brain, respectively [158].

\section{Role in Extinction Learning}

The BLA plays an integral role in the formation of associations between drugs of abuse and environmental cues and contexts [168-172] as well as the relationship between negative affective states due to withdrawal and the environmental cues and contexts experienced in those aversive states [173]. Conditioned fear studies have provided evidence that inhibition of normal learning and memory components within the BLA such as NMDA receptor function [174, 175], MAPK [176], phosphatidylinositol 3kinase (PI-3K) [177], L-type calcium channels [178], calcineurin [177], and de novo protein synthesis [176, 178, 179] attenuate the extinction of conditioned fear. Therefore, activity in the BLA appears to be necessary for drug-related cues and contexts to influence instrumental behavior [180, 181] such as cue-induced reinstatement of cocaine-seeking behavior [182, 183]. Furthermore, both current and former drug addicts exposed to drug-related cues (e.g., pictures of needles or drugs) show increased activity in the amygdala $[184,185]$.

Manipulation of various neurotransmitter systems in the BLA has been shown to affect the extinction of drug-seeking behavior. Facilitation of glutamatergic transmission enhances extinction of drug-seeking behavior [81, 83, 186188]. It is likely that additional neurotransmitter systems, including dopamine and acetylcholine, are also involved in the extinction of drug-cue/context associations [3, 189-191]. Several recent studies have shown that enhancement of cholinergic and glutamatergic transmission in the BLA facilitates the extinction of a drug-paired CPP [81, 190]. Schroeder and Packard have shown that the extinction of an amphetamine CPP involves cholinergic transmission in the BLA. In this study, direct infusions of the muscarinic acetylcholine receptor agonist oxotremorine facilitated the extinction of an amphetamine CPP [190]. In a previous study, these same investigators showed that local infusions of glucose also facilitated extinction of an amphetamine CPP [192]. Botreau and colleagues enhanced NMDA receptor function, which has been shown to mediate the consolidation of drug-related memories [184, 185, 193], with local infusions into the BLA of DCS to facilitate the extinction of a cocaine CPP [81]. In this study, control animals maintained a preference for the cocaine-paired chamber until their sixth extinction session whereas DCS treated animals extinguished a cocaine CPP after only three extinction sessions and maintained a neutral preference in extinction tests 3 and 14 days later [81]. Taken together as a whole, these findings suggest that the amygdala is involved in the extinction of drug-cue associations [81, 189, 190, 192].

\section{THE HIPPOCAMPUS}

\section{Functional Role and Anatomical Connectivity}

The hippocampus is a densely packed scrolled structure located within the medial temporal lobe that can be divided into several subregions including the dorsal hippocampus [which includes the dentate gyrus (DG) and cornu ammonis 1 (CA1)], ventrolateral hippocampus (which includes the subiculum and cornu ammonis 3 (CA3) and 2 additional cornu ammonis regions (CA2 and CA4) [194]. There is a continuous pathway of information moving through the hippocampus that originates and terminates at the sensory cortices and also that begins in the hippocampus at a gap between the subiculum and DG known as the perforant pathway [151, 194, 195]. After information enters the hippocampus, the entorhinal cortex (EC) synapses on cells in the DG which projects to CA3, then onto CA1, and back to the subiculum. The subiculum then regulates the transmission of information to the hypothalamus and mammillary bodies (via the fornix) or the relay of information to the EC thereby propelling information back to the sensory cortex [194, 196]. Afferent projections are received from a number of subcortical inputs including the amygdala, medial septum and diagonal band of Broca, claustrum, substantia innonminata and basal nucleus of Meynert, thalamus, lateral preoptic and lateral hypothalamic areas, supramammillary and retromammillary regions, VTA, tegmental reticular fields, raphe nuclei, dorsal tegmental nucleus, and the locus coeruleus [194]. The hippocampus plays a role in memory for context [197-205], context specific encoding [206, 207] and retrieval [207-209], episodic memory consolidation and retrieval $[156,210,211]$ as well as the storage of emotional memories through interactions with the amygdala [156].

\section{Role in Extinction Learning}

Previous research indicates that the hippocampus is an important neural substrate in extinction learning [206-209, 212-217]. For example, the extinction of conditioned appetitive responses to natural rewards [217], and drugseeking behavior [218-221] involve various subregions of the hippocampus including the EC, subiculum and CA1. Hippocampal lesions impair the extinction of a conditioned response to stimuli previously paired with a natural appetitive reward (e.g., sucrose) [217]. Imaging studies suggest that a pathway between the vmPFC and left anterior hippocampus is necessary for the recall of a contextdependent extinction memory [216] and an enhancement of entorhinal projections to the hippocampus facilitates extinction recall and memory $[135,216]$. Furthermore, Fuchs and colleagues have displayed that the dorsal hippocampus is an integral neural substrate that mediates contextual reinstatement of extinguished cocaine-seeking behavior [222].

Various molecular and biochemical processes within the hippocampus are associated with extinction learning. For example, activation of MAPKs [223], SRC tyrosine kinases [214], protein synthesis [56], NMDA receptors, and protein kinase A (PKA) [224] are necessary for the consolidation of extinction learning. Neuronal changes in activity have been observed in the CA1 and dentate gyrus regions of the hippocampus as a result of extinction training following cocaine self-administration [220]. Cocaine selfadministration also enhances hippocampal LTP [225-227], which has been shown to persist into extinction following cocaine self-administration [228]. Maintenance of LTP in the hippocampus 10 days post-extinction of cocaine selfadministration was nearly identical to LTP in the hippocampus of cocaine self-administering animals suggesting that neuronal changes in the brain due to cocaine use may facilitate long term changes in the hippocampus. 
Diminishing or reversing these changes may be necessary for facilitating the extinction of drug-associated memories and behaviors [228].

\section{THE DORSAL AND VENTRAL STRIATUM}

\section{Functional Role and Anatomical Connectivity}

The striatum is divided into a dorsal and ventral section. Both sections have observable anatomical subdivisions. The dorsal striatum is comprised of the caudate and putamen while the olfactory tubercle and Acb make up the ventral region. The Acb is located where the head of the caudate and anterior portion of the putamen meet. It is often divided into the AcbC and AcbSh. The striatum is the primary input zone of the basal ganglia. Afferent projections are received from a number of different brain regions including the PFC, amygdala, VTA, hippocampus, GP, and subthalamic nucleus [229-232]. Efferent signals are first mediated by the ventral pallidum and passed on to the dorsomedial thalamus and PFC [230].

As part of the extrapyramidal motor system and the largest component of the basal ganglia, the striatum is well known for the pivotal role it plays in mediating different aspects of reward [161, 180, 233]. Striatal subregions are also involved in multiple facets of learning and memory, including appetitive conditioning and instrumental learning [65, 234-237]. Furthermore, the striatum is involved with motor control, action selection, habit learning, and various other cognitive processes involving executive function [238, 239].

\section{Role in Extinction Learning}

Recent evidence suggests that the striatum may mediate extinction learning [137, 240]. Unfortunately, conflicting results from inactivation studies have provided different hypotheses regarding the striatum's role in extinction [241243]. For instance, lesions to the Acb have been shown to facilitate [241] but also inhibit extinction [242, 243] of instrumental responding to natural rewards.

Clearly, striatal subregions are an important subcomponent in mediating reward-related stimuli [180, 244, 245]. Following the presentation of unexpected rewards, reward-related stimuli $[233,245,246]$, and aversive stimuli [247, 248], functional magnetic resonance imaging (fMRI) studies show that there is an increase in striatal activity. Dopaminergic neurons projecting from the midbrain to the striatum have been implicated in responses to novel stimuli $[249,250]$, unexpected rewards $[244,251]$ and aversive stimuli [252] and may underlie the prioritizing of salient stimuli through a reallocation of brain resources [238]. Specifically, dopaminergic innervation from the ventral midbrain to Acb has repeatedly been shown to be involved in the primary rewarding and reinforcing effects of various drugs of abuse (see $[253,254]$ for recent reviews). On the other hand, dorsal regions [219] appear to play a key role in the transition from casual to compulsive drug use [10, 210 , $255,256]$. Here, glutamatergic substrates are believed to be necessary for cue-controlled cocaine-seeking behavior [257]. Finally, it is worth noting that inactivation of dorsal regions blocks cue-induced reinstatement of cocaine-seeking behavior [258] while the inhibition of extracellular signalregulated kinase (ERK) in the $\mathrm{AcbC}$ region results in a lasting attenuation of drug-induced reinstatement of cocaine conditioned place preference as well as cocaine-induced phosphorylation of several signaling molecules including ERKs, cAMP response element binding, Elk-1 and fos [259].

Extinction training involves a number of neurochemical and molecular processes in the striatum [240, 249, 260-262]. As such, there is evidence that extinction procedures following cocaine self-administration produce various hallmarks of neuronal plasticity in the Acb [258, 262]. For example, extinction training restores cocaine-induced deficits in tyrosine hydroxylase immunoreactivity in the AcbSh [262]. On the other hand, these investigators found that animals not undergoing extinction training showed a persistent reduction in levels of the enzyme following cocaine self-administration [262]. At the same time, other research has shown that cocaine-induced deficits in levels of the NR1 subunit of the NMDA receptor in the AcbC are normalized after extinction training [261]. Extinction training also induces an upregulation in the expression of the GluR1 and GluR2/3 subunits of the AMPA receptor in the Acb [240, 260], and virally-mediated upregulation of these AMPA subunits in this region facilitates extinction learning [240]. Consistent with this, GluR1 deletion in mice results in resistance to extinction following cocaine or food selfadministration [263]. These lines of evidence show a considerable amount of neuroplasticity in the Acb during extinction learning of drug-associated memories and thus may serve as a novel therapeutic site for the treatment of drug addiction.

\section{CONCLUSION}

Learning and memory processes have been hypothesized to underlie drug addiction [1, 5]. Many common neural mechanisms exist between mnemonic systems and drugaddiction making a greater understanding of the neurobiological mechanisms underlying extinction of drugrelated memories and behaviors an essential task for future research. While it is clear that drug-associated cues can elicit craving and therefore serve as an obstacle to treatment, they also provide a potential site for the development of novel therapeutics for addiction The majority of research examining the neurobiological mechanisms of extinction learning have centered on non-drug rewards or aversive conditioning, but recent studies have emerged indicating that the PFC, amygdala, hippocampus and striatum are important components that mediate the extinction of drug-associated memories and behavior [81, 190, 220, 228, 240, 258, 260, 262].

The extent to which pathways among these structures interact to mediate extinction learning is not fully understood but recent evidence provides multiple candidate regions (see [136] for a review) including, PrLC projections to the basal nucleus of the amygdala, LA, and CE mediating the expression of conditioned fear [264]. Conversely, projections from the ILC excite GABAergic neurons in the intercalated [265] cell masses inhibiting the CE thereby promoting the extinction of conditioned fear [266]. The expression of cocaine- and heroin- seeking behavior involves projections from the PrLC to the AcbC [267-272], whereas projections from the ILC to the AcbSh mediate the extinction of cocaine-seeking behavior [137]. 
Clearly, more research is needed for determining the complex interactions among these structures, including hippocampal and striatal connections possibly mediating the extinction of drug-associated memories. Elucidation of the neural mechanisms underlying extinction learning of drugrelated memories depends on sophisticated novel experimental methods in order to truly understand the neuroanatomical structures underlying the formation and extinction of memories related to drug addiction. Future research should also examine the influence of different neurotransmitter systems on extinction learning. For example, within the PFC, activation of the cannabinoid CB1 receptors facilitates the extinction of conditioned fear whereas inhibition of the same receptor attenuates extinction of conditioned fear [266]. Determining the role and amount of impact that agonists acting at CB1, glutamate, or GABA receptor sites have on the extinction of drug-associated memories may help answer important questions regarding the neuroanatomical circuits underlying the extinction of drug-associated memories.

\section{ACKNOWLEDGEMENTS}

RMC is supported by research grant DA024355 from the National Institute on Drug Abuse and JTG is supported by grant 1F32AA017820 from the National Institute on Alcohol Abuse and Alcoholism. Both authors have no conflicts of interest to declare.

$$
\begin{array}{ll}
\text { ABBREVIATIONS } \\
\mathrm{Acb} \quad=\text { Nucleus accumbens } \\
\mathrm{AcbSh} \quad=\text { Nucleus accumbens shell } \\
\mathrm{ACC} \quad=\text { Anterior cingulate cortex } \\
\mathrm{AMPA} \quad=\alpha \text {-Amino-3-hydroxyl-5-methyl-4-isoxazole- } \\
\text { propionate } \\
\mathrm{BLA}=\text { Basolateral amygdala } \\
\mathrm{CA} 1 \quad=\text { Cornu ammonis } 1 \\
\mathrm{CA} 2 & =\text { Cornu ammonis } 2 \\
\mathrm{CA} 3 & =\text { Cornu ammonis } 3 \\
\mathrm{CA} 4 & =\text { Cornu ammonis } 4 \\
\mathrm{CCK} & =\text { Cholecystokinin } \\
\mathrm{CPP} & =\text { Conditioned place preference } \\
\mathrm{CPP} & =3-(+-) 2-\text { Carboxypiperazin-4yl propel-1 } \\
& \text { phosphate } \\
\mathrm{CPu} & =\text { Caudate-putamen } \\
\mathrm{CRF} & =\text { Corticotropin releasing factor } \\
\mathrm{CS} & =\text { Conditioned stimulus } \\
\mathrm{DCS} & =\text { D-cycloserine (D-4-amino-3-isoxazolidone) } \\
\mathrm{DG} & =\text { Dentate gyrus } \\
\mathrm{dmPFC} & =\text { Dorsomedial prefrontal cortex } \\
\mathrm{EC} & =\text { Entorhinal cortex } \\
\mathrm{fMRI} & =\text { Functional magnetic resonance imaging } \\
\mathrm{GABA} & =\text { Gamma-Aminobutyric acid } \\
\mathrm{GP} & =\text { Globus pallidus } \\
&
\end{array}
$$

$$
\begin{array}{ll}
\text { ILC } & =\text { Infralimbic cortex } \\
\text { IVSA } & =\text { Intravenous drug self-administration } \\
\text { IOFC } & =\text { Lateral orbitofrontal cortex } \\
\text { LTD } & =\text { Long-term depression } \\
\text { LTP } & =\text { Long-term potentiation } \\
\text { MAPK } & =\text { Mitogen-activated protein kinase } \\
\text { mOFC } & =\text { Medial orbitofrontal cortex } \\
\text { mPFC } & =\text { Medial prefrontal cortex } \\
\text { NMDA } & =\text { N-methyl-D-aspartate } \\
\text { NPY } & =\text { Neuropeptide Y } \\
\text { OFC } & =\text { Orbitofrontal cortex } \\
\text { PFC } & =\text { Prefrontal cortex } \\
\text { PI-3K } & =\text { Phosphatidylinositol 3-kinase } \\
\text { PKA } & =\text { Protein kinase A } \\
\text { Pir } & =\text { Piriform cortex } \\
\text { PrLC } & =\text { Prelimbic cortex } \\
\text { US } & =\text { Unconditioned stimulus } \\
\text { vmPFC } & \text { Ventromedial prefrontal cortex } \\
\text { VTA } & =\text { Ventral tegmental area }
\end{array}
$$

\section{REFERENCES}

[1] Kelley AE. Memory and addiction: shared neural circuitry and molecular mechanisms. Neuron 2004; 44: 161-79.

[2] Robbins TW, Ersche KD, Everitt BJ. Drug addiction and the memory systems of the brain. Ann N Y Acad Sci 2008; 1141: 1-21.

[3] Dalley JW, Everitt BJ. Dopamine receptors in the learning, memory and drug reward circuitry. Semin Cell Dev Biol 2009; 20: 403-10.

[4] Kauer JA. Learning mechanisms in addiction: synaptic plasticity in the ventral tegmental area as a result of exposure to drugs of abuse. Annu Rev Physiol 2004; 66: 447-75.

[5] Hyman SE. Addiction: a disease of learning and memory. Am J Psychiatry 2005; 162: 1414-22.

[6] Hyman SE, Malenka RC, Nestler EJ. Neural mechanisms of addiction: the role of reward-related learning and memory. Annu Rev Neurosci 2006; 29: 565-98.

[7] O'Brien CP, Childress AR, McLellan AT, Ehrman R. A learning model of addiction. Res Publ Assoc Res Nerv Ment Dis 1992; 70: 157-77.

[8] Boning J. Addiction memory as a specific, individually learned memory imprint. Pharmacopsychiatry 2009; 42(Suppl 1): S66-8.

[9] Di Chiara G, Tanda G, Bassareo V, et al. Drug addiction as a disorder of associative learning. Role of nucleus accumbens shell/extended amygdala dopamine. Ann N Y Acad Sci 1999; 877 : 461-85.

[10] Weiss F. Neurobiology of craving, conditioned reward and relapse. Curr Opin Pharmacol 2005; 5: 9-19.

[11] Wise RA. Dopamine, learning and motivation. Nat Rev Neurosci 2004; 5: 483-94.

[12] Childress AR, Hole AV, Ehrman RN, Robbins SJ, McLellan AT, $\mathrm{O}^{\prime}$ Brien $\mathrm{CP}$. Cue reactivity and cue reactivity interventions in drug dependence. NIDA Res Monogr 1993; 137: 73-95.

[13] O'Brien CP, Childress AR, Ehrman R, Robbins SJ. Conditioning factors in drug abuse: can they explain compulsion? J Psychopharmacol 1998; 12: 15-22.

[14] Kalivas PW, Volkow ND. The neural basis of addiction: pathology of motivation and choice. Am J Psychiatry 2005; 162: 1403-13.

[15] Conklin CA, Tiffany ST. Applying extinction research and theory to cue-exposure addiction treatments. Addiction 2002; 97: 155-67. 
[16] Childress AR, McLellan AT, Ehrman RN, O'Brien CP. Extinction of conditioned responses in abstinent cocaine or opioid users. NIDA Res Monogr 1987; 76: 189-95.

[17] O'Brien CP, Childress AR, McLellan AT, Ehrman R. Developing treatments that address classical conditioning. NIDA Res Monogr 1993; 135: 71-91

[18] O'Brien CP, Childress AR, McLellan T, Ehrman R. Integrating systemic cue exposure with standard treatment in recovering drug dependent patients. Addict Behav 1990; 15: 355-65.

[19] Childress AR, McLellan AT, O'Brien CP. Behavioral therapies for substance abuse. Int J Addict 1985; 20: 947-69.

[20] Nader K. Memory traces unbound. Trends Neurosci 2003; 26: 6572

[21] Tronson NC, Taylor JR. Molecular mechanisms of memory reconsolidation. Nat Rev Neurosci 2007; 8: 262-75.

[22] Dudai Y, Eisenberg M. Rites of passage of the engram: reconsolidation and the lingering consolidation hypothesis. Neuron 2004; 44: 93-100.

[23] Alberini CM. Mechanisms of memory stabilization: are consolidation and reconsolidation similar or distinct processes? Trends Neurosci 2005; 28: 51-6.

[24] Lee JL, Di Ciano P, Thomas KL, Everitt BJ. Disrupting reconsolidation of drug memories reduces cocaine-seeking behavior. Neuron 2005; 47: 795-801.

[25] Olmstead MC. Animal models of drug addiction: Where do we go from here? Q J Exp Psychol (Colchester) 2006; 59: 625-53.

[26] Sanchis-Segura C, Spanagel R. Behavioural assessment of drug reinforcement and addictive features in rodents: an overview. Addict Biol 2006; 11: 2-38

[27] Kalivas PW, Peters J, Knackstedt L. Animal models and brain circuits in drug addiction. Mol Interv 2006; 6: 339-44.

[28] Panlilio LV, Goldberg SR. Self-administration of drugs in animals and humans as a model and an investigative tool. Addiction 2007; 102: $1863-70$

[29] Epstein DH, Preston KL, Stewart J, Shaham Y. Toward a model of drug relapse: an assessment of the validity of the reinstatement procedure. Psychopharmacology (Berl) 2006; 189: 1-16.

[30] Gardner EL. What we have learned about addiction from animal models of drug self-administration. Am J Addict 2000; 9: 285-313.

[31] Gardner EL. Use of animal models to develop antiaddiction medications. Curr Psychiatr Rep 2008; 10: 377-84.

[32] O'Brien CP, Gardner EL. Critical assessment of how to study addiction and its treatment: human and non-human animal models. Pharmacol Ther 2005; 108: 18-58

[33] See RE. Neural substrates of cocaine-cue associations that trigger relapse. Eur J Pharmacol 2005; 526: 140-6.

[34] Shalev U, Grimm JW, Shaham Y. Neurobiology of relapse to heroin and cocaine seeking: a review. Pharmacol Rev 2002; 54: 142

[35] Sinha R. The role of stress in addiction relapse. Curr Psychiatry Rep 2007; 9: 388-95.

[36] Stewart J. Review. Psychological and neural mechanisms of relapse. Philos Trans R Soc Lond B Biol Sci 2008; 363: 3147-58.

[37] Sinha R, Fuse T, Aubin LR, O'Malley SS. Psychological stress, drug-related cues and cocaine craving. Psychopharmacology (Berl) 2000; 152: 140-8.

[38] Sinha R. How does stress increase risk of drug abuse and relapse? Psychopharmacology (Berl) 2001; 158: 343-59

[39] Stewart J. Pathways to relapse: the neurobiology of drug- and stress-induced relapse to drug-taking. J Psychiatry Neurosci 2000; 25: 125-36.

[40] Stewart J. Stress and relapse to drug seeking: studies in laboratory animals shed light on mechanisms and sources of long-term vulnerability. Am J Addict 2003; 12: 1-17.

[41] Hammersley R. Cue exposure and learning theory. Addict Behav 1992; 17: 297-300.

[42] Corty EW, Coon B. The extinction of naturally occurring conditioned reactions in psychoactive substance users: analog studies. Addict Behav 1995; 20: 605-18.

[43] Di Ciano P, Everitt BJ. Reinstatement and spontaneous recovery of cocaine-seeking following extinction and different durations of withdrawal. Behav Pharmacol 2002; 13: 397-405.

[44] Tobena A, Fernandez-Teruel A, Escorihuela RM, et al. Limits of habituation and extinction: implications for relapse prevention programs in addictions. Drug Alcohol Depend 1993; 32: 209-17.
[45] Bouton ME. Context, time, and memory retrieval in the interference paradigms of Pavlovian learning. Psychol Bull 1993; 114: 80-99

[46] Bouton ME. Context, ambiguity, and unlearning: sources of relapse after behavioral extinction. Biol Psychiatry 2002; 52: 976-86.

[47] Bouton ME. Context and behavioral processes in extinction. Learn Mem 2004; 11: 485-94.

[48] Bouton ME, Swartzentruber D. Sources of relapse after extinction in Pavlovian and instrumental learning. Clin Psychol Rev 1991; 11: 123-40.

[49] Bouton ME, Westbrook RF, Corcoran KA, Maren S. Contextual and temporal modulation of extinction: behavioral and biological mechanisms. Biol Psychiatry 2006; 60: 352-60.

[50] Rescorla RA. Preservation of Pavlovian associations through extinction. Q J Exp Psychol B 1996; 49: 245 - 58.

[51] Milad MR, Orr SP, Pitman RK, Rauch SL. Context modulation of memory for fear extinction in humans. Psychophysiology 2005; 42 : 456-64.

[52] Crombag HS, Shaham Y. Renewal of drug seeking by contextual cues after prolonged extinction in rats. Behav Neurosci 2002; 116 169-73.

[53] Carroll ME. Acquisition and reacquisition (relapse) of drug abuse: modulation by alternative reinforcers. NIDA Res Monogr 1998; 169: 6-25.

[54] Grasing $\mathrm{K}, \mathrm{He} \mathrm{S}, \mathrm{Li}$ N. Selegiline modifies the extinction of responding following morphine self-administration, but does not alter cue-induced reinstatement, reacquisition of morphine reinforcement, or precipitated withdrawal. Pharmacol Res 2005; 51: 69-78.

[55] Yang YL, Lu KT. Facilitation of conditioned fear extinction by dcycloserine is mediated by mitogen-activated protein kinase and phosphatidylinositol 3-kinase cascades and requires de novo protein synthesis in basolateral nucleus of amygdala. Neuroscience 2005; 134: 247-60.

[56] Vianna MR, Szapiro G, McGaugh JL, Medina JH, Izquierdo I. Retrieval of memory for fear-motivated training initiates extinction requiring protein synthesis in the rat hippocampus. Proc Natl Acad Sci U S A 2001; 98: 12251-4.

[57] Tzschentke TM. Measuring reward with the conditioned place preference (CPP) paradigm: update of the last decade. Addict Biol 2007; 12: 227-462.

[58] Crombag HS, Bossert JM, Koya E, Shaham Y. Review. Contextinduced relapse to drug seeking: a review. Philos Trans R Soc Lond B Biol Sci 2008; 363: 3233-43.

[59] Epstein DH, Preston KL. The reinstatement model and relapse prevention: a clinical perspective. Psychopharmacology (Berl) 2003; 168: 31-41.

[60] Burattini C, Gill TM, Aicardi G, Janak PH. The ethanol selfadministration context as a reinstatement cue: acute effects of naltrexone. Neuroscience 2006; 139: 877-87.

[61] Alleweireldt AT, Weber SM, Neisewander JL. Passive exposure to a contextual discriminative stimulus reinstates cocaine-seeking behavior in rats. Pharmacol Biochem Behav 2001; 69: 555-60.

[62] Kelley JB, Anderson KL, Itzhak Y. Long-term memory of cocaineassociated context: disruption and reinstatement. Neuroreport 2007 18: 777-80

[63] Tsiang MT, Janak PH. Alcohol seeking in C57BL/6 mice induced by conditioned cues and contexts in the extinction-reinstatement model. Alcohol 2006; 38: 81-8.

[64] Zironi I, Burattini C, Aicardi G, Janak PH. Context is a trigger for relapse to alcohol. Behav Brain Res 2006; 167: 150-5.

[65] Kelley AE. Ventral striatal control of appetitive motivation: role in ingestive behavior and reward-related learning. Neurosci Biobehav Rev 2004; $27:$ 765-76.

[66] Nestler EJ. Is there a common molecular pathway for addiction? Nat Neurosci 2005; 8: 1445-9.

[67] Berke JD, Hyman SE. Addiction, dopamine, and the molecular mechanisms of memory. Neuron 2000; 25: 515-32.

[68] Hyman SE, Malenka RC. Addiction and the brain: the neurobiology of compulsion and its persistence. Nat Rev Neurosci 2001; 2: 695-703.

[69] Davis M, Myers KM, Chhatwal J, Ressler KJ. Pharmacological treatments that facilitate extinction of fear: relevance to psychotherapy. NeuroRx 2006; 3: 82-96. 
[70] Davis M, Ressler K, Rothbaum BO, Richardson R. Effects of Dcycloserine on extinction: translation from preclinical to clinical work. Biol Psychiatry 2006; 60: 369-75.

[71] Gillespie CF, Ressler KJ. Emotional learning and glutamate: translational perspectives. CNS Spectr 2005; 10: 831-9.

[72] Ledgerwood L, Richardson R, Cranney J. D-cycloserine facilitates extinction of learned fear: effects on reacquisition and generalized extinction. Biol Psychiatry 2005; 57: 841-7.

[73] Ledgerwood L, Richardson R, Cranney J. D-cycloserine and the facilitation of extinction of conditioned fear: consequences for reinstatement. Behav Neurosci 2004; 118: 505-13.

[74] Ledgerwood L, Richardson R, Cranney J. Effects of D-cycloserine on extinction of conditioned freezing. Behav Neurosci 2003; 117: 341-9.

[75] Parnas AS, Weber M, Richardson R. Effects of multiple exposures to D-cycloserine on extinction of conditioned fear in rats. Neurobiol Learn Mem 2005; 83: 224-31.

[76] Ressler KJ, Rothbaum BO, Tannenbaum L, et al. Cognitive enhancers as adjuncts to psychotherapy: use of D-cycloserine in phobic individuals to facilitate extinction of fear. Arch Gen Psychiatry 2004; 61: 1136-44.

[77] Richardson R, Ledgerwood L, Cranney J. Facilitation of fear extinction by D-cycloserine: theoretical and clinical implications. Learn Mem 2004; 11: 510-6.

[78] Woods AM, Bouton ME. D-cycloserine facilitates extinction but does not eliminate renewal of the conditioned emotional response. Behav Neurosci 2006; 120: 1159-62.

[79] Mao SC, Hsiao YH, Gean PW. Extinction training in conjunction with a partial agonist of the glycine site on the NMDA receptor erases memory trace. J Neurosci 2006; 26: 8892-9.

[80] Walker DL, Ressler KJ, Lu KT, Davis M. Facilitation of conditioned fear extinction by systemic administration or intraamygdala infusions of D-cycloserine as assessed with fearpotentiated startle in rats. J Neurosci 2002; 22: 2343-51.

[81] Botreau F, Paolone G, Stewart J. d-Cycloserine facilitates extinction of a cocaine-induced conditioned place preference. Behav Brain Res 2006; 172: 173-8.

[82] Paolone G, Botreau F, Stewart J. The facilitative effects of Dcycloserine on extinction of a cocaine-induced conditioned place preference can be long lasting and resistant to reinstatement. Psychopharmacology (Berl) 2009; 202: 403-9.

[83] Thanos PK, Bermeo C, Wang GJ, Volkow ND. D-cycloserine accelerates the extinction of cocaine-induced conditioned place preference in C57bL/c mice. Behav Brain Res 2009; 199: 345-9.

[84] Bowery NG. Glycine-binding sites and NMDA receptors in brain. Nature 1987; 326: 338.

[85] Hood WF, Compton RP, Monahan JB. D-cycloserine: a ligand for the N-methyl-D-aspartate coupled glycine receptor has partial agonist characteristics. Neurosci Lett 1989; 98: 91-5.

[86] Nic Dhonnchadha BA, Szalay JJ, Achat-Mendes C, et al. Dcycloserine deters reacquisition of cocaine self-administration by augmenting extinction learning. Neuropsychopharmacology 2010; 35: 357-67.

[87] Moussawi K, Pacchioni A, Moran M, et al. N-Acetylcysteine reverses cocaine-induced metaplasticity. Nat Neurosci 2009; 12: $182-9$.

[88] Fuster J. The prefrontal cortex: anatmoy, physiology, and neuropsychology of the frontal lobe. New York: Raven Press 1997.

[89] Shidara M, Richmond BJ. Anterior cingulate: single neuronal signals related to degree of reward expectancy. Science 2002; 296: 1709-11.

[90] Tzschentke TM. The medial prefrontal cortex as a part of the brain reward system. Amino Acids 2000; 19: 211-9.

[91] Vertes RP. Interactions among the medial prefrontal cortex, hippocampus and midline thalamus in emotional and cognitive processing in the rat. Neuroscience 2006; 142: 1-20.

[92] Glickman SE. Perseverative neural processes and consolidation of the memory trace. Psychol Bull 1961; 58: 218-33.

[93] McGaugh JL. Time-dependent processes in memory storage. Science 1966; 153: 1351-8.

[94] Likhtik E, Pelletier JG, Paz R, Pare D. Prefrontal control of the amygdala. J Neurosci 2005; 25: 7429-37.

[95] Morgane PJ, Galler JR, Mokler DJ. A review of systems and networks of the limbic forebrain/limbic midbrain. Prog Neurobiol 2005; 75: 143-60.
[96] Sesack SR, Deutch AY, Roth RH, Bunney BS. Topographical organization of the efferent projections of the medial prefrontal cortex in the rat: an anterograde tract-tracing study with Phaseolus vulgaris leucoagglutinin. J Comp Neurol 1989; 290: 213-42.

[97] Vertes RP. Differential projections of the infralimbic and prelimbic cortex in the rat. Synapse 2004; 51:32-58.

[98] Oades RD, Halliday GM. Ventral tegmental (A10) system: neurobiology. 1. Anatomy and connectivity. Brain Res 1987; 434: 117-65.

[99] Taber MT, Das S, Fibiger HC. Cortical regulation of subcortical dopamine release: mediation via the ventral tegmental area. J Neurochem 1995; 65: 1407-10.

[100] Retaux S, Caboche J, Rogard M, Julien JF, Penit-Soria J, Besson MJ. GABA interneurons in the rat medial frontal cortex: characterization by quantitative in situ hybridization of the glutamic acid decarboxylase (GAD67) mRNA. Brain Res 1993; 611: 187-96.

[101] Retaux S, Julien JF, Besson MJ, Penit-Soria J. Expression of GAD mRNA in GABA interneurons of the rat medial frontal cortex. Neurosci Lett 1992; 136: 67-71.

[102] Lidov HG, Grzanna R, Molliver ME. The serotonin innervation of the cerebral cortex in the rat--an immunohistochemical analysis. Neuroscience 1980; 5: 207-27.

[103] Reader TA. Distribution of catecholamines and serotonin in the rat cerebral cortex: absolute levels and relative proportions. J Neural Transm 1981; 50: 13-27.

[104] Steinbusch HW. Distribution of serotonin-immunoreactivity in the central nervous system of the rat-cell bodies and terminals. Neuroscience 1981; 6: 557-618.

[105] Lewis DA, Morrison JH. Noradrenergic innervation of monkey prefrontal cortex: a dopamine-beta-hydroxylase immunohistochemical study. J Comp Neurol 1989; 282: 317-30.

[106] Morrison JH, Molliver ME, Grzanna R, Coyle JT. The intracortical trajectory of the coeruleo-cortical projection in the rat: a tangentially organized cortical afferent. Neuroscience 1981; 6: 13958.

[107] Swanson LW, Hartman BK. The central adrenergic system. An immunofluorescence study of the location of cell bodies and their efferent connections in the rat utilizing dopamine-beta-hydroxylase as a marker. J Comp Neurol 1975; 163: 467-505.

[108] Satoh K, Fibiger HC. Cholinergic neurons of the laterodorsal tegmental nucleus: efferent and afferent connections. J Comp Neurol 1986; 253: 277-302.

[109] Gaykema RP, Luiten PG, Nyakas C, Traber J. Cortical projection patterns of the medial septum-diagonal band complex. J Comp Neurol 1990; 293: 103-24.

[110] Lehmann J, Nagy JI, Atmadia S, Fibiger HC. The nucleus basalis magnocellularis: the origin of a cholinergic projection to the neocortex of the rat. Neuroscience 1980; 5: 1161-74.

[111] Luiten PG, Gaykema RP, Traber J, Spencer DG, Jr. Cortical projection patterns of magnocellular basal nucleus subdivisions as revealed by anterogradely transported Phaseolus vulgaris leucoagglutinin. Brain Res 1987; 413: 229-50.

[112] Steketee JD. Neurotransmitter systems of the medial prefrontal cortex: potential role in sensitization to psychostimulants. Brain Res Brain Res Rev 2003; 41: 203-28.

[113] Quirk GJ, Garcia R, Gonzalez-Lima F. Prefrontal mechanisms in extinction of conditioned fear. Biol Psychiatry 2006; 60: 337-43.

[114] Quirk GJ, Beer JS. Prefrontal involvement in the regulation of emotion: convergence of rat and human studies. Curr Opin Neurobiol 2006; 16: 723-7.

[115] Sotres-Bayon F, Cain CK, LeDoux JE. Brain mechanisms of fear extinction: historical perspectives on the contribution of prefrontal cortex. Biol Psychiatry 2006; 60: 329-36.

[116] Quirk GJ, Russo GK, Barron JL, Lebron K. The role of ventromedial prefrontal cortex in the recovery of extinguished fear. J Neurosci 2000; 20: 6225-31.

[117] Fernandez Espejo E. Prefrontocortical dopamine loss in rats delays long-term extinction of contextual conditioned fear, and reduces social interaction without affecting short-term social interaction memory. Neuropsychopharmacology 2003; 28: 490-8.

[118] Lebron K, Milad MR, Quirk GJ. Delayed recall of fear extinction in rats with lesions of ventral medial prefrontal cortex. Learn Mem 2004; 11: 544-8. 
[119] Morgan MA, LeDoux JE. Differential contribution of dorsal and ventral medial prefrontal cortex to the acquisition and extinction of conditioned fear in rats. Behav Neurosci 1995; 109: 681-8.

[120] Morgan MA, Romanski LM, LeDoux JE. Extinction of emotional learning: contribution of medial prefrontal cortex. Neurosci Lett 1993; 163: 109-13.

[121] Morgan MA, Schulkin J, LeDoux JE. Ventral medial prefrontal cortex and emotional perseveration: the memory for prior extinction training. Behav Brain Res 2003; 146: 121-30.

[122] Sierra-Mercado D, Jr., Corcoran KA, Lebron-Milad K, Quirk GJ. Inactivation of the ventromedial prefrontal cortex reduces expression of conditioned fear and impairs subsequent recall of extinction. Eur J Neurosci 2006; 24: 1751-8.

[123] Weible AP, McEchron MD, Disterhoft JF. Cortical involvement in acquisition and extinction of trace eyeblink conditioning. Behav Neurosci 2000; 114: 1058-67.

[124] Gewirtz JC, Falls WA, Davis M. Normal conditioned inhibition and extinction of freezing and fear-potentiated startle following electrolytic lesions of medical prefrontal cortex in rats. Behav Neurosci 1997; 111: 712-26.

[125] Morgan MA, LeDoux JE. Contribution of ventrolateral prefrontal cortex to the acquisition and extinction of conditioned fear in rats. Neurobiol Learn Mem 1999; 72: 244-51.

[126] Hugues S, Deschaux O, Garcia R. Postextinction infusion of a mitogen-activated protein kinase inhibitor into the medial prefrontal cortex impairs memory of the extinction of conditioned fear. Learn Mem 2004; 11: 540-3.

[127] Santini E, Ge H, Ren K, Pena de Ortiz S, Quirk GJ. Consolidation of fear extinction requires protein synthesis in the medial prefrontal cortex. J Neurosci 2004; 24: 5704-10.

[128] Hugues S, Chessel A, Lena I, Marsault R, Garcia R. Prefrontal infusion of PD098059 immediately after fear extinction training blocks extinction-associated prefrontal synaptic plasticity and decreases prefrontal ERK2 phosphorylation. Synapse 2006; 60: 280-7.

[129] Burgos-Robles A, Vidal-Gonzalez I, Santini E, Quirk GJ. Consolidation of fear extinction requires NMDA receptordependent bursting in the ventromedial prefrontal cortex. Neuron 2007; 53: 871-80.

[130] Sotres-Bayon F, Diaz-Mataix L, Bush DE, LeDoux JE. Dissociable roles for the ventromedial prefrontal cortex and amygdala in fear extinction: NR2B contribution. Cereb Cortex 2009; 19: 474-82.

[131] Milad MR, Quirk GJ. Neurons in medial prefrontal cortex signal memory for fear extinction. Nature 2002; 420: 70-4.

[132] Milad MR, Vidal-Gonzalez I, Quirk GJ. Electrical stimulation of medial prefrontal cortex reduces conditioned fear in a temporally specific manner. Behav Neurosci 2004; 118: 389-94.

[133] Vidal-Gonzalez I, Vidal-Gonzalez B, Rauch SL, Quirk GJ. Microstimulation reveals opposing influences of prelimbic and infralimbic cortex on the expression of conditioned fear. Learn Mem 2006; 13: 728-33.

[134] Phelps EA, Delgado MR, Nearing KI, LeDoux JE. Extinction learning in humans: role of the amygdala and vmPFC. Neuron 2004; 43: 897-905.

[135] Milad MR, Wright CI, Orr SP, Pitman RK, Quirk GJ, Rauch SL. Recall of fear extinction in humans activates the ventromedial prefrontal cortex and hippocampus in concert. Biol Psychiatry 2007; 62: 446-54.

[136] Peters J, Kalivas PW, Quirk GJ. Extinction circuits for fear and addiction overlap in prefrontal cortex. Learn Mem 2009; 16: 27988.

[137] Peters J, LaLumiere RT, Kalivas PW. Infralimbic prefrontal cortex is responsible for inhibiting cocaine seeking in extinguished rats. $\mathrm{J}$ Neurosci 2008; 28: 6046-53.

[138] Volkow ND, Hitzemann R, Wang GJ, et al. Long-term frontal brain metabolic changes in cocaine abusers. Synapse 1992; 11: 184-90.

[139] Beveridge TJ, Smith HR, Daunais JB, Nader MA, Porrino LJ. Chronic cocaine self-administration is associated with altered functional activity in the temporal lobes of non human primates. Eur J Neurosci 2006; 23: 3109-18.

[140] Jentsch JD, Taylor JR. Impulsivity resulting from frontostriatal dysfunction in drug abuse: implications for the control of behavior by reward-related stimuli. Psychopharmacology (Berl) 1999; 146: 373-90.
[141] Goldstein RZ, Tomasi D, Rajaram S, et al. Role of the anterior cingulate and medial orbitofrontal cortex in processing drug cues in cocaine addiction. Neuroscience 2007; 144: 1153-9.

[142] Bonson KR, Grant SJ, Contoreggi CS, et al. Neural systems and cue-induced cocaine craving. Neuropsychopharmacology 2002; 26: 376-86.

[143] Childress AR, Mozley PD, McElgin W, Fitzgerald J, Reivich M, $\mathrm{O}$ 'Brien CP. Limbic activation during cue-induced cocaine craving. Am J Psychiatry 1999; 156: 11-8.

[144] Garavan H, Pankiewicz J, Bloom A, et al. Cue-induced cocaine craving: neuroanatomical specificity for drug users and drug stimuli. Am J Psychiatry 2000; 157: 1789-98.

[145] Grant S, London ED, Newlin DB, et al. Activation of memory circuits during cue-elicited cocaine craving. Proc Natl Acad Sci USA 1996; 93: 12040-5.

[146] Kilts CD, Schweitzer JB, Quinn CK, et al. Neural activity related to drug craving in cocaine addiction. Arch Gen Psychiatry 2001; 58: $334-41$.

[147] Maas LC, Lukas SE, Kaufman MJ, et al. Functional magnetic resonance imaging of human brain activation during cue-induced cocaine craving. Am J Psychiatry 1998; 155: 124-6.

[148] Volkow ND, Wang GJ, Fowler JS, et al. Association of methylphenidate-induced craving with changes in right striatoorbitofrontal metabolism in cocaine abusers: implications in addiction. Am J Psychiatry 1999; 156: 19-26.

[149] Wexler BE, Gottschalk CH, Fulbright RK, et al. Functional magnetic resonance imaging of cocaine craving. Am J Psychiatry 2001; 158: 86-95.

[150] Isoda M, Hikosaka O. Switching from automatic to controlled action by monkey medial frontal cortex. Neurosci $2007 ; 10: 240-8$.

[151] Cahill L, McGaugh JL, Weinberger NM. The neurobiology of learning and memory: some reminders to remember. Trends Neurosci 2001; 24: 578-81.

[152] Cahill L, Babinsky R, Markowitsch HJ, McGaugh JL. The amygdala and emotional memory. Nature 1995; 377: 295-6.

[153] LaBar KS, Cabeza R. Cognitive neuroscience of emotional memory. Nat Rev Neurosci 2006; 7: 54-64.

[154] Maren S. Building and burying fear memories in the brain. Neuroscientist 2005; 11: 89-99.

[155] McGaugh JL. The amygdala modulates the consolidation of memories of emotionally arousing experiences. Annu Rev Neurosci 2004; 27: 1-28.

[156] Phelps EA. Human emotion and memory: interactions of the amygdala and hippocampal complex. Curr Opin Neurobiol 2004; 14: $198-202$.

[157] Rodrigues SM, Schafe GE, LeDoux JE. Molecular mechanisms underlying emotional learning and memory in the lateral amygdala. Neuron 2004; 44: 75-91.

[158] Balleine BW, Killcross S. Parallel incentive processing: an integrated view of amygdala function. Trends Neurosci 2006; 29: 272-9.

[159] Baxter MG, Murray EA. The amygdala and reward. Nat Rev Neurosci 2002; 3: 563-73.

[160] Blundell P, Hall G, Killcross S. Lesions of the basolateral amygdala disrupt selective aspects of reinforcer representation in rats. J Neurosci 2001; 21: 9018-26.

[161] Everitt BJ, Cador M, Robbins TW. Interactions between the amygdala and ventral striatum in stimulus-reward associations: studies using a second-order schedule of sexual reinforcement. Neuroscience 1989; 30: 63-75.

[162] Everitt BJ, Cardinal RN, Parkinson JA, Robbins TW. Appetitive behavior: impact of amygdala-dependent mechanisms of emotional learning. Ann N Y Acad Sci 2003; 985: 233-50.

[163] Hatfield T, Han JS, Conley M, Gallagher M, Holland P. Neurotoxic lesions of basolateral, but not central, amygdala interfere with Pavlovian second-order conditioning and reinforcer devaluation effects. J Neurosci 1996; 16: 5256-65.

[164] See RE, Fuchs RA, Ledford CC, McLaughlin J. Drug addiction, relapse, and the amygdala. Ann N Y Acad Sci 2003; 985: 294-307.

[165] De Olmos J BC, Alheid G. Amygdala and extended amygdala of the rat: a cytoarchitectonical, fibroarchitectonical, and chemicoarchitectonical survey. In: Paxinos G, Ed. The Rat Nervous System. San Diego: Academic Press; 2004; pp. 509-603.

[166] Pitkanen A. Connectivity of the rat amygdaloid complex. In: Aggleton JP, Ed. The Amygdala: A Functional Analysis. Oxford: Oxford University Press; 2000; pp. 31-115. 
[167] Olive MF. Metabotropic glutamate receptor ligands as potential therapeutics for addiction. Curr Drug Abuse Rev 2009; 2: 83-98.

[168] Brown EE, Fibiger HC. Differential effects of excitotoxic lesions of the amygdala on cocaine-induced conditioned locomotion and conditioned place preference. Psychopharmacology (Berl) 1993; 113: 123-30.

[169] Everitt BJ, Morris KA, O'Brien A, Robbins TW. The basolateral amygdala-ventral striatal system and conditioned place preference: further evidence of limbic-striatal interactions underlying rewardrelated processes. Neuroscience 1991; 42: 1-18.

[170] Hiroi N, White NM. The lateral nucleus of the amygdala mediates expression of the amphetamine-produced conditioned place preference. J Neurosci 1991; 11: 2107-16.

[171] Rizos Z, Ovari J, Leri F. Reconditioning of heroin place preference requires the basolateral amygdala. Pharmacol Biochem Behav 2005; 82: 300-5.

[172] Whitelaw RB, Markou A, Robbins TW, Everitt BJ. Excitotoxic lesions of the basolateral amygdala impair the acquisition of cocaine-seeking behaviour under a second-order schedule of reinforcement. Psychopharmacology (Berl) 1996; 127: 213-24.

[173] Schulteis G, Ahmed SH, Morse AC, Koob GF, Everitt BJ. Conditioning and opiate withdrawal. Nature 2000; 405: 1013-4.

[174] Sotres-Bayon F, Bush DE, LeDoux JE. Acquisition of fear extinction requires activation of NR2B-containing NMDA receptors in the lateral amygdala. Neuropsychopharmacology 2007; 32: $1929-40$.

[175] Falls WA, Miserendino MJ, Davis M. Extinction of fearpotentiated startle: blockade by infusion of an NMDA antagonist into the amygdala. J Neurosci 1992; 12: 854-63.

[176] Lu KT, Walker DL, Davis M. Mitogen-activated protein kinase cascade in the basolateral nucleus of amygdala is involved in extinction of fear-potentiated startle. J Neurosci 2001; 21: RC162.

[177] Lin CH, Yeh SH, Leu TH, Chang WC, Wang ST, Gean PW. Identification of calcineurin as a key signal in the extinction of fear memory. J Neurosci 2003; 23: 1574-9.

[178] Lin CH, Yeh SH, Lu HY, Gean PW. The similarities and diversities of signal pathways leading to consolidation of conditioning and consolidation of extinction of fear memory. $\mathrm{J}$ Neurosci 2003; 23: 8310-7.

[179] Suzuki A, Josselyn SA, Frankland PW, Masushige S, Silva AJ, Kida S. Memory reconsolidation and extinction have distinct temporal and biochemical signatures. J Neurosci 2004; 24: 478795.

[180] Cador M, Robbins TW, Everitt BJ. Involvement of the amygdala in stimulus-reward associations: interaction with the ventral striatum. Neuroscience 1989; 30: 77-86.

[181] Burns LH, Everitt BJ, Robbins TW. Effects of excitotoxic lesions of the basolateral amygdala on conditional discrimination learning with primary and conditioned reinforcement. Behav Brain Res 1999; 100: 123-33.

[182] Meil WM, See RE. Lesions of the basolateral amygdala abolish the ability of drug associated cues to reinstate responding during withdrawal from self-administered cocaine. Behav Brain Res 1997; 87: 139-48.

[183] Kantak KM, Black Y, Valencia E, Green-Jordan K, Eichenbaum HB. Dissociable effects of lidocaine inactivation of the rostral and caudal basolateral amygdala on the maintenance and reinstatement of cocaine-seeking behavior in rats. J Neurosci 2002; 22: 1126-36.

[184] Childress AR, Ehrman RN, Wang Z, et al. Prelude to passion: limbic activation by "unseen" drug and sexual cues. PLoS One 2008; 3: e1506.

[185] Zhang X, Chen X, Yu Y, et al. Masked smoking-related images modulate brain activity in smokers. Hum Brain Mapp 2009; 30: 896-907.

[186] Gass JT, Olive MF. Positive allosteric modulation of mGluR5 receptors facilitates extinction of a cocaine contextual memory. Biol Psychiatry 2009; 65: 717-20.

[187] Vengeliene V, Kiefer F, Spanagel R. D-cycloserine facilitates extinction of conditioned alcohol-seeking behaviour in rats. Alcohol Alcohol 2008; 43: 626-9.

[188] Zhou W, Kalivas PW. N-acetylcysteine reduces extinction responding and induces enduring reductions in cue- and heroininduced drug-seeking. Biol Psychiatry 2008; 63: 338-40.

[189] Schroeder JP, Packard MG. Posttraining intra-basolateral amygdala scopolamine impairs food- and amphetamine-induced conditioned place preferences. Behav Neurosci 2002; 116: 922-7.
[190] Schroeder JP, Packard MG. Facilitation of memory for extinction of drug-induced conditioned reward: role of amygdala and acetylcholine. Learn Mem 2004; 11: 641-7.

[191] Di Ciano P, Everitt BJ. Direct interactions between the basolateral amygdala and nucleus accumbens core underlie cocaine-seeking behavior by rats. J Neurosci 2004; 24: 7167-73.

[192] Schroeder JP, Packard MG. Systemic or intra-amygdala injections of glucose facilitate memory consolidation for extinction of druginduced conditioned reward. Eur J Neurosci 2003; 17: 1482-8.

[193] Milton AL, Lee JL, Butler VJ, Gardner R, Everitt BJ. Intraamygdala and systemic antagonism of NMDA receptors prevents the reconsolidation of drug-associated memory and impairs subsequently both novel and previously acquired drug-seeking behaviors. J Neurosci 2008; 28: 8230-7.

[194] Andersen P. The hippocampus book. New York: Oxford University Press 2007.

[195] Malin EL, McGaugh JL. Differential involvement of the hippocampus, anterior cingulate cortex, and basolateral amygdala in memory for context and footshock. Proc Natl Acad Sci U S A 2006; 103: 1959-63.

196] Baddeley A, Bueno O, Cahill L, et al. The brain decade in debate: I. Neurobiology of learning and memory. Braz J Med Biol Res 2000; 33: 993-1002.

[197] Good M, Honey RC. Conditioning and contextual retrieval in hippocampal rats. Behav Neurosci 1991; 105: 499-509.

[198] Kim JJ, Fanselow MS. Modality-specific retrograde amnesia of fear. Science 1992; 256: 675-7.

[199] Phillips RG, LeDoux JE. Differential contribution of amygdala and hippocampus to cued and contextual fear conditioning. Behav Neurosci 1992; 106: 274-85.

[200] Honey RC, Good M. Selective hippocampal lesions abolish the contextual specificity of latent inhibition and conditioning. Behav Neurosci 1993; 107: 23-33.

[201] Maren S, Aharonov G, Fanselow MS. Neurotoxic lesions of the dorsal hippocampus and Pavlovian fear conditioning in rats. Behav Brain Res 1997; 88: 261-74.

[202] Frankland PW, Cestari V, Filipkowski RK, McDonald RJ, Silva AJ. The dorsal hippocampus is essential for context discrimination but not for contextual conditioning. Behav Neurosci 1998; 112: 863-74.

[203] Good M, de Hoz L, Morris RG. Contingent vs incidental context processing during conditioning: dissociation after excitotoxic hippocampal plus dentate gyrus lesions. Hippocampus 1998; 8: 147-59.

[204] Rudy JW, O'Reilly RC. Conjunctive representations, the hippocampus, and contextual fear conditioning. Cogn Affect Behav Neurosci 2001; 1: 66-82.

[205] Kennedy PJ, Shapiro ML. Retrieving memories via internal context requires the hippocampus. J Neurosci 2004; 24: 6979-85.

[206] Corcoran KA, Desmond TJ, Frey KA, Maren S. Hippocampal inactivation disrupts the acquisition and contextual encoding of fear extinction. J Neurosci 2005; 25: 8978-87.

[207] Ji J, Maren S. Electrolytic lesions of the dorsal hippocampus disrupt renewal of conditional fear after extinction. Learn Mem 2005; $12: 270-6$.

[208] Corcoran KA, Maren S. Hippocampal inactivation disrupts contextual retrieval of fear memory after extinction. J Neurosci 2001; 21: 1720-6.

[209] Corcoran KA, Maren S. Factors regulating the effects of hippocampal inactivation on renewal of conditional fear after extinction. Learn Mem 2004; 11: 598-603.

[210] Izquierdo I, Bevilaqua LR, Rossato JI, Bonini JS, Medina JH, Cammarota M. Different molecular cascades in different sites of the brain control memory consolidation. Trends Neurosci 2006; 29: 496-505.

[211] Shapiro ML, Kennedy PJ, Ferbinteanu J. Representing episodes in the mammalian brain. Curr Opin Neurobiol 2006; 16: 701-9.

[212] Wilson A, Brooks DC, Bouton ME. The role of the rat hippocampal system in several effects of context in extinction. Behav Neurosci 1995; 109: 828-36.

[213] Frohardt RJ, Guarraci FA, Bouton ME. The effects of neurotoxic hippocampal lesions on two effects of context after fear extinction. Behav Neurosci 2000; 114: 227-40.

[214] Bevilaqua LR, da Silva WN, Medina JH, Izquierdo I, Cammarota $\mathrm{M}$. Extinction and reacquisition of a fear-motivated memory require activity of the Src family of tyrosine kinases in the CA1 
region of the hippocampus. Pharmacol Biochem Behav 2005; 81: 139-45.

[215] Bevilaqua LR, Bonini JS, Rossato JI, Izquierdo LA, Cammarota M, Izquierdo I. The entorhinal cortex plays a role in extinction. Neurobiol Learn Mem 2006; 85: 192-7.

[216] Kalisch R, Korenfeld E, Stephan KE, Weiskopf N, Seymour B, Dolan RJ. Context-dependent human extinction memory is mediated by a ventromedial prefrontal and hippocampal network. J Neurosci 2006; 26: 9503-11.

[217] Chan KH, Jarrard LE, Davidson TL. The effects of selective ibotenate lesions of the hippocampus on conditioned inhibition and extinction. Cogn Affect Behav Neurosci 2003; 3: 111-9.

[218] Vorel SR, Liu X, Hayes RJ, Spector JA, Gardner EL. Relapse to cocaine-seeking after hippocampal theta burst stimulation. Science 2001; 292: 1175-8.

[219] Sun W, Akins CK, Mattingly AE, Rebec GV. Ionotropic glutamate receptors in the ventral tegmental area regulate cocaine-seeking behavior in rats. Neuropsychopharmacology 2005; 30: 2073-81.

[220] Neisewander JL, Baker DA, Fuchs RA, Tran-Nguyen LT, Palmer A, Marshall JF. Fos protein expression and cocaine-seeking behavior in rats after exposure to a cocaine self-administration environment. J Neurosci 2000; 20: 798-805.

[221] Meyers RA, Zavala AR, Neisewander JL. Dorsal, but not ventral, hippocampal lesions disrupt cocaine place conditioning. Neuroreport 2003; 14: 2127-31.

[222] Fuchs RA, Evans KA, Ledford CC, et al. The role of the dorsomedial prefrontal cortex, basolateral amygdala, and dorsal hippocampus in contextual reinstatement of cocaine seeking in rats. Neuropsychopharmacology 2005; 30: 296-309.

[223] Rossato JI, Bevilaqua LR, Lima RH, Medina JH, Izquierdo I, Cammarota M. On the participation of hippocampal p38 mitogenactivated protein kinase in extinction and reacquisition of inhibitory avoidance memory. Neuroscience 2006; 143: 15-23.

[224] Szapiro G, Vianna MR, McGaugh JL, Medina JH, Izquierdo I. The role of NMDA glutamate receptors, PKA, MAPK, and CAMKII in the hippocampus in extinction of conditioned fear. Hippocampus 2003; 13: 53-8.

[225] Del Olmo N, Higuera-Matas A, Miguens M, et al. Hippocampal synaptic plasticity and water maze learning in cocaine selfadministered rats. Ann N Y Acad Sci 2006; 1074: 427-37.

[226] Thompson AM, Gosnell BA, Wagner JJ. Enhancement of longterm potentiation in the rat hippocampus following cocaine exposure. Neuropharmacology 2002; 42: 1039-42.

[227] Thompson AM, Swant J, Gosnell BA, Wagner JJ. Modulation of long-term potentiation in the rat hippocampus following cocaine self-administration. Neuroscience 2004; 127: 177-85.

[228] Del Olmo N, Miguens M, Higuera-Matas A, et al. Enhancement of hippocampal long-term potentiation induced by cocaine selfadministration is maintained during the extinction of this behavior. Brain Res 2006; 1116: 120-6.

[229] Mailly P, Charpier S, Mahon S, et al. Dendritic arborizations of the rat substantia nigra pars reticulata neurons: spatial organization and relation to the lamellar compartmentation of striato-nigral projections. J Neurosci 2001; 21: 6874-88.

[230] Deschenes M, Bourassa J, Parent A. Striatal and cortical projections of single neurons from the central lateral thalamic nucleus in the rat. Neuroscience 1996; 72: 679-87.

[231] McDonald AJ. Topographical organization of amygdaloid projections to the caudatoputamen, nucleus accumbens, and related striatal-like areas of the rat brain. Neuroscience 1991; 44: 15-33.

[232] McDonald AJ. Organization of amygdaloid projections to the prefrontal cortex and associated striatum in the rat. Neuroscience 1991; 44: 1-14.

[233] Berns GS, McClure SM, Pagnoni G, Montague PR. Predictability modulates human brain response to reward. J Neurosci 2001; 21 : 2793-8.

[234] Setlow B. The nucleus accumbens and learning and memory. J Neurosci Res 1997; 49: 515-21.

[235] Parkinson JA, Cardinal RN, Everitt BJ. Limbic cortical-ventral striatal systems underlying appetitive conditioning. Prog Brain Res 2000; 126: 263-85.

[236] Deadwyler SA, Hayashizaki S, Cheer J, Hampson RE. Reward, memory and substance abuse: functional neuronal circuits in the nucleus accumbens. Neurosci Biobehav Rev 2004; 27: 703-11.
[237] Cardinal RN, Everitt BJ. Neural and psychological mechanisms underlying appetitive learning: links to drug addiction. Curr Opin Neurobiol 2004; 14: 156-62.

[238] Redgrave P, Prescott TJ, Gurney K. The basal ganglia: a vertebrate solution to the selection problem? Neuroscience 1999; 89: 1009-23.

[239] Cardinal RN, Parkinson JA, Hall J, Everitt BJ. Emotion and motivation: the role of the amygdala, ventral striatum, and prefrontal cortex. Neurosci Biobehav Rev 2002; 26: 321-52.

[240] Sutton MA, Schmidt EF, Choi KH, et al. Extinction-induced upregulation in AMPA receptors reduces cocaine-seeking behaviour. Nature 2003; 421: 70-5.

[241] Pothuizen HH, Feldon J, Yee BK. Facilitated extinction of appetitive instrumental conditioning following excitotoxic lesions of the core or the medial shell subregion of the nucleus accumbens in rats. Exp Brain Res 2006; 172: 120-8.

[242] de Borchgrave R, Rawlins JN, Dickinson A, Balleine BW. Effects of cytotoxic nucleus accumbens lesions on instrumental conditioning in rats. Exp Brain Res 2002; 144: 50-68.

[243] Annett LE, McGregor A, Robbins TW. The effects of ibotenic acid lesions of the nucleus accumbens on spatial learning and extinction in the rat. Behav Brain Res 1989; 31: 231-42.

[244] Mirenowicz J, Schultz W. Importance of unpredictability for reward responses in primate dopamine neurons. J Neurophysiol 1994; 72: 1024-7.

[245] Delgado MR, Nystrom LE, Fissell C, Noll DC, Fiez JA. Tracking the hemodynamic responses to reward and punishment in the striatum. J Neurophysiol 2000; 84: 3072-7.

[246] Knutson B, Westdorp A, Kaiser E, Hommer D. FMRI visualization of brain activity during a monetary incentive delay task Neuroimage 2000; 12: 20-7.

[247] Becerra L, Breiter HC, Wise R, Gonzalez RG, Borsook D. Reward circuitry activation by noxious thermal stimuli. Neuron 2001; 32: 927-46.

[248] Jensen J, McIntosh AR, Crawley AP, Mikulis DJ, Remington G, Kapur S. Direct activation of the ventral striatum in anticipation of aversive stimuli. Neuron 2003; 40: 1251-7.

[249] Schultz W, Romo R. Dopamine neurons of the monkey midbrain: contingencies of responses to stimuli eliciting immediate behavioral reactions. J Neurophysiol 1990; 63: 607-24.

[250] Legault M, Wise RA. Novelty-evoked elevations of nucleus accumbens dopamine: dependence on impulse flow from the ventral subiculum and glutamatergic neurotransmission in the ventral tegmental area. Eur J Neurosci 2001; 13: 819-28.

[251] Schultz W. Predictive reward signal of dopamine neurons. J Neurophysiol 1998; 80: 1-27.

[252] Young AM. Increased extracellular dopamine in nucleus accumbens in response to unconditioned and conditioned aversive stimuli: studies using $1 \mathrm{~min}$ microdialysis in rats. $\mathrm{J}$ Neurosci Methods 2004; 138: 57-63.

[253] Di Chiara G, Bassareo V. Reward system and addiction: what dopamine does and doesn't do. Curr Opin Pharmacol 2007; 7: 6976.

[254] Bonci A, Bernardi G, Grillner P, Mercuri NB. The dopaminecontaining neuron: maestro or simple musician in the orchestra of addiction? Trends Pharmacol Sci 2003; 24: 172-7.

[255] Everitt BJ, Robbins TW. Neural systems of reinforcement for drug addiction: from actions to habits to compulsion. Nat Neurosci 2005; 8: 1481-9.

[256] Robbins TW, Everitt BJ. Limbic-striatal memory systems and drug addiction. Neurobiol Learn Mem 2002; 78: 625-36.

[257] Vanderschuren LJ, Di Ciano P, Everitt BJ. Involvement of the dorsal striatum in cue-controlled cocaine seeking. J Neurosci 2005; 25: 8665-70.

[258] Fuchs RA, Branham RK, See RE. Different neural substrates mediate cocaine seeking after abstinence $v s$ extinction training: a critical role for the dorsolateral caudate-putamen. J Neurosci 2006; 26: 3584-8

[259] Miller CA, Marshall JF. Molecular substrates for retrieval and reconsolidation of cocaine-associated contextual memory. Neuron 2005; 47: 873-84.

[260] Self DW. Regulation of drug-taking and -seeking behaviors by neuroadaptations in the mesolimbic dopamine system. Neuropharmacology 2004; 47(Suppl 1): 242-55.

[261] Self DW, Choi KH, Simmons D, Walker JR, Smagula CS. Extinction training regulates neuroadaptive responses to 
withdrawal from chronic cocaine self-administration. Learn Mem 2004; 11: 648-57.

[262] Schmidt EF, Sutton MA, Schad CA, Karanian DA, Brodkin ES, Self DW. Extinction training regulates tyrosine hydroxylase during withdrawal from cocaine self-administration. J Neurosci 2001; 21: RC137.

[263] Mead AN, Zamanillo D, Becker N, Stephens DN. AMPA-receptor GluR1 subunits are involved in the control over behavior by cocaine-paired cues. Neuropsychopharmacology 2007; 32: 343-53.

[264] Blair HT, Schafe GE, Bauer EP, Rodrigues SM, LeDoux JE. Synaptic plasticity in the lateral amygdala: a cellular hypothesis of fear conditioning. Learn Mem 2001; 8: 229-42.

[265] Finger EC, Mitchell DG, Jones M, Blair RJ. Dissociable roles of medial orbitofrontal cortex in human operant extinction learning. Neuroimage 2008; 43: 748-55.

[266] Li G, Nair SS, Quirk GJ. A biologically realistic network model of acquisition and extinction of conditioned fear associations in lateral amygdala neurons. J Neurophysiol 2009; 101: 1629-46.
[267] McLaughlin J, See RE. Selective inactivation of the dorsomedial prefrontal cortex and the basolateral amygdala attenuates conditioned-cued reinstatement of extinguished cocaine-seeking behavior in rats. Psychopharmacology (Berl) 2003; 168: 57-65.

[268] McFarland K, Kalivas PW. The circuitry mediating cocaineinduced reinstatement of drug-seeking behavior. J Neurosci 2001; 21: 8655-63.

[269] McFarland K, Davidge SB, Lapish CC, Kalivas PW. Limbic and motor circuitry underlying footshock-induced reinstatement of cocaine-seeking behavior. J Neurosci 2004; 24: 1551-60.

[270] Di Pietro NC, Black YD, Kantak KM. Context-dependent prefrontal cortex regulation of cocaine self-administration and reinstatement behaviors in rats. Eur J Neurosci 2006; 24: 3285-98.

[271] LaLumiere RT, Kalivas PW. Glutamate release in the nucleus accumbens core is necessary for heroin seeking. J Neurosci 2008; 28: 3170-7.

[272] Rogers JL, Ghee S, See RE. The neural circuitry underlying reinstatement of heroin-seeking behavior in an animal model of relapse. Neuroscience 2008; 151: 579-88.

(C) Cleva and Gass; Licensee Bentham Open.

This is an open access article licensed under the terms of the Creative Commons Attribution Non-Commercial License (http://creativecommons.org/licenses/by$\mathrm{nc} / 3.0 /$ ) which permits unrestricted, non-commercial use, distribution and reproduction in any medium, provided the work is properly cited. 